\title{
The Effects of Performance Management System on Employee Performance.: A Study
}

\author{
Md. Aktaruzzaman Santi *, Abdur Rahim ** \\ * Department of Management Studies, University of Barishal \\ ** Department of Management Studies, University of Barishal \\ DOI: 10.29322/IJSRP.11.08.2021.p11661 \\ http://dx.doi.org/10.29322/IJSRP.11.08.2021.p11661
}

\begin{abstract}
The purpose of the study was to determine the influence of performance management (PM) on employee productivity in the Consumer Food Products Ltd. More specifically, the study sought to determine the extent to which performance appraisal, explore the extent to which training and development and determine the extent to which rewarding systems and contrast the extent to which feedback and coaching influence on employee productivity. In order to test four (04) hypothesis and achieve the objectives of this research structured questionnaire had been applied to gather primary data for analysis and interpretation. However, this questionnaire is composed of 30 questions (Likert Scale question) that personate all the variables of this paper. However, a random sample ( $\mathrm{n}=61$ ) was selected with 75 questionnaires that were distributed and back to ensure high response from staffs. The analysis of data is divided into three main section; Descriptive Statistics (Mean, Standard deviation, Standard error mean,); Inferential Statistics (Reliability test,); Structural Model ( $\mathrm{t}$-value, $\mathrm{p}$-value, Coefficient value) to find the linkage between PMS practice and selected outcomes by using SPSS (Statistical Package for Social Science)-16. Tables were used to present the findings. The research concludes the result of the data analysis reveal that PMS (F\&C: $\beta=.280, t=2.237, p=.029 . T \& D: \beta=.522, t=4.696, p=.000 . P A: \beta=.230, t=1.814, p=.075$. RS: $\beta=068, t=.525, p=.601)$ have a significant influence on its selected outcomes. As a result, it is recommended by the researcher that study also brought about the emphasis on the presence and appearance of PMS internal experts within the organizations which helps to improve the implementation of effective PMS practices. The study concluded that there are no links between performance appraisal and employee performance as indicated.
\end{abstract}

Index Terms- Employee performance management, Performance evaluation, Performance planning, Employee performance management satisfaction, Job satisfaction Strain, Policing

\section{INTRODUCTION}

Global businesses are operating in the midst of challenging times. An organization today, in order to be profitable and ahead of its peers, needs to compete in more markets, operate across more platforms and manage more stakeholders than ever before (Beckons). One of the important elements in the organizational orderliness of human resource management is performance management (Zulystiawati, Vol.3, No.4, 2014). Even the term "performance management" is much more recent, and so there is much less history to describe (DeNisi \& Murphy, 2017,). This research has been focused on improving the performance of individuals, however, and the ultimate goal of performance management systems is to improve firm-level performance. Possible Outcomes from Effective Performance Management: clarifying job responsibilities and expectations, enhancing individual and group productivity, developing employee capabilities to their fullest extent through effective feedback and coaching, driving behavior to align with the organization's core values, goals and strategy (Pulakos E. D). Performance management is regarded as the - Achilles Heel of human capital management and it is the most difficult system to implement in organization (Pulakos E. D., 2009, p. 3). It should thus be managers' top priority (Almothaseb, Almahameed, \& Tobeery, June 2017). Organizations need to be aware of face more realistically towards keeping their human resources up-to-date. In so doing, managers need to pay special attention to all the core functions of human resource management (Nassazi, 2013), and performance management is one of them.

\section{Literature Review}

The idea of Performance Management System (PMS) constitutes one of the important and positive developments that have gained momentum in the domain of Human Resource Management (HRM) recently (Armstrong, 1994, P.01). Performance management (PM) includes activities which ensure that goals are consistently being met in an effective and efficient manner. Performance management potentially makes the most significant contribution to individual and organizational learning and helps to raise organizational efficiency and promote growth (Adhikari, 2010). Performance management has to be the core of all organizations since it gives strategic direction and how resources are going to be distributed towards the achievement of set goals and objectives. Performance management is a tool meant to improve performance and productivity and it is yet to be fully institutionalized as the way of doing business. Effective performance management in the public service requires specific tools and deliberate measures (Olufemi). The aim of performance management is to improve service delivery through effective and efficient application of resources (Zvavahera). At the very outset, it is 
worthwhile to point out that there is nothing new in the concept of PMS as its origin can be traced back as early as 221-265 AD (Assish, March 2018). The essence of management as a set of complex procedures and activities is influencing on a particular system in order to change the system towards achieving defined development objectives (Tomić, Tadić, \& Sedlak, November 2016.). Performance measurement system, as stated by Nelly et al. (2003), relates to the use of multidimensional set of indicators (financial, non-financial, internal, and external). The role of performance measurement system as a subsystem is identified as part of the strategic performance management, whereby the performance management system is responsible for the implementation process (Rastislav \& Petra, September 2016).

\section{DATA ANALYSIS}

\section{Hypotheses Development and Data Analysis:}

\section{Theoretical Framework:}

The theoretical framework is the "blueprint" for the entire dissertation inquiry. It serves as the guide on which to build and support your study, and also provides the structure to define how you will philosophically, epistemologically, methodologically, and analytically approach the dissertation as a whole. defined a theoretical framework as "a structure that guides research by relying on a formal theory...constructed by using an established, coherent explanation of certain phenomena and relationships". Thus, the theoretical framework consists of the selected theory (or theories) that undergird your thinking with regards to how you understand and plan to research your topic, as well as the concepts and definitions from that theory that are relevant to your topic. Criteria for applying or developing theories to the dissertation that must be appropriate, logically interpreted, well understood, and align with the question at hand.

\section{* Training \& Development:}

Accordingly, training refers to the methods used to give new or present employees the skills that they need to perform their jobs. Additionally, the focus of training is performance improvement, which are directed towards maintaining and improving current job performance (Desseler, 2007, p. 270).

\section{THE FIVE STEPS OF TRAINING}

Gary Dessler opine that training consists of the five steps:

a. Training Needs Analysis (TNA): Identifies the specific job performance skills needed, assesses the prospective trainees' skills, and develops specific measurable knowledge and performance objectives based on any deficiencies.

b. Training Instructional Design (TID) is to decide, compile and produce training program content, including workbooks, exercises, and activities and some techniques like computer and on the job training technique.

c. Training Validation: The bugs are worked out of the training program by presenting it to a small representative audience.

d. Implementation: Actually, training the targeted employee group.

e. Evaluation: Management assess the program's success or failures.

\section{MEASURING TRAINING EFFECTS}

The effects of training can be measured through the following four basic categories of outcome.

- Reaction

- Learning

- Behavior

- Results

\section{* Coaching \& Feedback:}

Coaching, in its simplest form, means to train, tutor or give instruction. It is an excellent skill that can be used to enhance growth and performance, as well as promote individual responsibility and accountability. Performance coaching is an ongoing process which helps build and maintain effective employee and supervisory relationships. Performance coaching can help identify an employee's growth, as well as help plan and develop new skills. Feedback is the primary tool used to provide employees with information and guidance. Feedback consists of two-way communication.

Employee feedback provides managers with clues regarding how they are hindering or aiding their subordinates' work performance. 
Supervisory feedback should inform, enlighten, and suggest improvements to employees regarding their performance. Supervisors should describe specific results they have observed as close to the event as possible so ideas stay fresh and any needed adjustments can be made in a timely manner. Successful supervisors develop a routine that includes frequent, in-depth discussions about performance with employees.

360 Degree Feedback In recent years, there has been a growing interest in multi-rater or 360-degree feedback, in response to an increasing need for greater employee commitment and empowerment. In essence, 360-degree feedback enables all the stakeholders in a person's performance to comment and give feedback (Ward, 1995). Stakeholders may include peers, subordinates, internal/

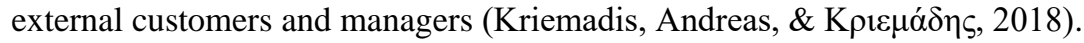

\section{EXISTING APPROACHES}

Eclectic Interventions Eclectic coaching interventions are activities that derive from no particular theoretical per spectate but have considerable face validity nonetheless, in that a lay person would be likely to assume that they would help a team perform well. Eclectic models are found mainly in the practitioner literature as codifications of the les sons learned by management consultants whose practice includes team facilitation.

Process Consultation The process consultation approach developed by Schein $(1969,1988)$ posits that competent interpersonal relations are essential for effective task performance and that group members themselves must be intimately involved in analyzing and improving those relationships. The consultant engages team members in analyzing group processes on two levels simultaneously: (1) the substantive level- To analyze how human processes are affecting work on a specific organizational problem? And (2) the internal level-to better understand the team's own interaction processes and the ways that team processes foster or impede effective group functioning.

Behavioral Models Two distinct models of team coaching are based on theories of individual behavior: (1) the application of Argyris's (1982, 1993) theory of intervention to team-focused coaching by Schwarz (1994) and (2) applications of parent conditioning to the modification of team behavior, notably those of Komaki $(1986,1998)$ and her col leagues (Richard \& Ruth, 2005).

\section{* Performance Appraisal}

A performance appraisal is a regular review of an employee's job performance and overall contribution to a company. Also known as an "annual review," "performance review or evaluation," or "employee appraisal," a performance appraisal evaluates an employee's skills, achievements and growth, or lack thereof. Companies use performance appraisals to give employees big-picture feedback on their work and to justify pay increases and bonuses, as well as termination decisions.

\section{Cognitive Placement for Performance Appraisal}

The method of cognitive placement determines the performance groups among employees. HR managers appoint the performance grade of employees into one group. Top performers and bad performers are interested to HR managers, because top performers make up the "talent management" group and bad performers make up the "performance management" group. Talent performers might be candidates for management positions, because they have the best individual performance, while bad performers may need performance management process to upgrade their knowledge and individual performance. So, we make the scale of cognitive placements follows (see Figure).

\begin{tabular}{crrrrrr}
100 & 90 & 70 & 50 & 30 & 10 & 0 (Grades) \\
\hline $10 \%$ & $20 \%$ & $20 \%$ & $20 \%$ & $20 \%$ & $10 \%$
\end{tabular}

Top individual performance has the performance grade of 90-100, while bad performance has the lowest grade of 10. In addition, the two groups might be the target group of HR managers and HR departments. HR manager replaces the top $10 \%$ of employees into top performers and replaces the lowest $10 \%$ of employees into bad performer group.

\section{* Rewarding System:}

Procedures, rules, and standards associated with allocation of benefits and compensation to employees. The reward system is a group of neural structures responsible for incentive salience (i.e., motivation and "wanting", desire, or craving for a reward), associative learning (primarily positive reinforcement and classical conditioning), and positively-valanced emotions, particularly ones which involve pleasure as a core component (e.g., joy, euphoria and ecstasy). 


\subsection{Conceptual Framework:}

For SPSSS analysis, one dependent variable and four independent variables are chosen. Independent variables are training and development (T\&D), on-going feedback and coaching, performance appraisal, rewarding systems. And level of satisfaction of PMS practices are considered the dependent variable.

\section{Independent Variables}

\section{Dependent Variable}

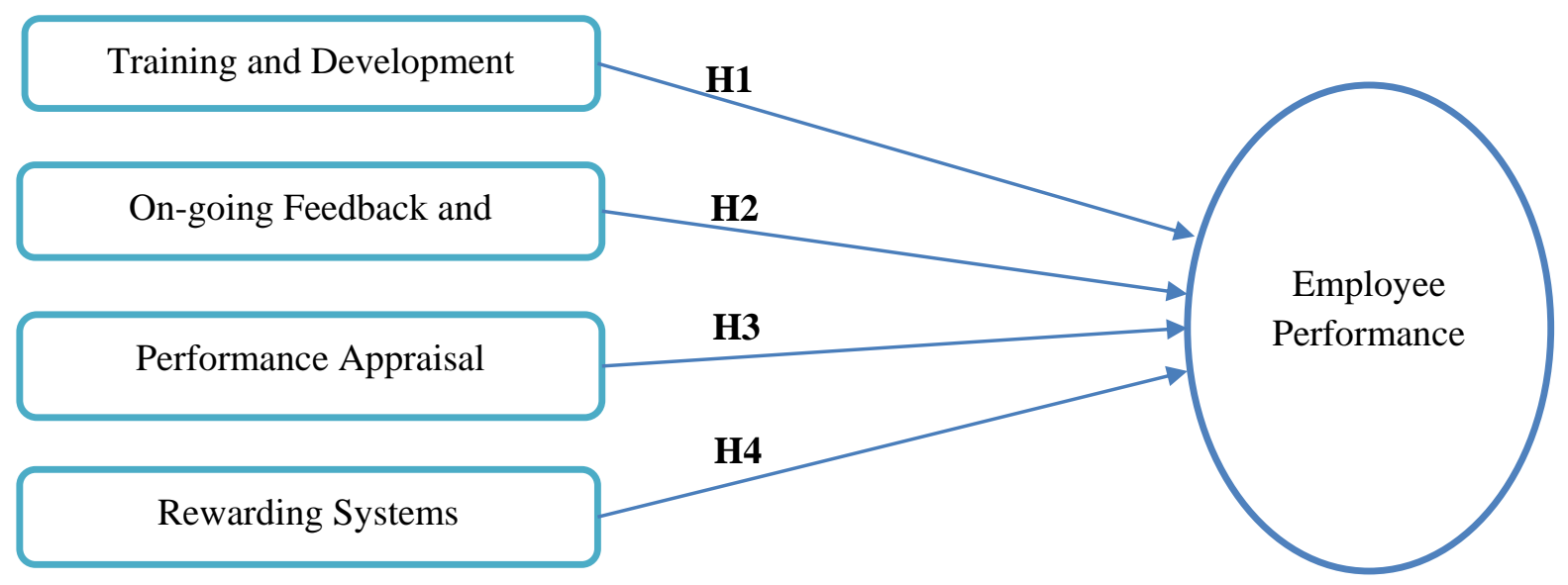

Figure 1:Conceptual Framework

\section{Data Analysis:}

\subsection{Analytical Model:}

A mathematical model is developed for my research. I have to use multiple regression equation to identify as well as analyze the dependent and independent variables. There are total ten variables consist of nine independent variables and a dependent variable. The mathematical model is bellow-

$\dot{Y}=\alpha+\beta_{1} X+\beta_{2} X+\beta_{3} x+\beta_{4} x+e$

Here,

$\dot{\mathbf{Y}}=$ Dependent variable, which is employee satisfaction level of PMS of the company.

$\boldsymbol{B}_{1 \mathbf{x}}=$ Training \& Development (Independent variable)

$\mathbf{B}_{\mathbf{2}} \mathbf{x}=$ Feedback \& Coaching (Independent variable)

$\mathbf{B}_{3 \mathbf{X}}=$ Performance Appraisal (Independent variable)

$\mathbf{B}_{\mathbf{4}} \mathbf{x}=$ Rewarding System (Independent variable)

$\mathbf{e}=$ Error

\subsection{Research Question Development:}

RQ1: Does Training \& Development significantly influence employee satisfaction?

RQ2: Does Feedback \& Coaching significantly influence employee performance?

RQ3: Does Performance Appraisal significantly influence the employee satisfaction?

RQ4: Does Rewarding System significantly influence the employee satisfaction?

\section{Reliability Analysis of Factors}

Table 1: Reliability Analysis of Factors

\begin{tabular}{|l|c|c|}
\hline \multicolumn{1}{|c|}{ Groups } & Number of Items & Cronbach's Alpha \\
\hline Dependent Variable: & 6 & .860 \\
\hline Employee Performance & & \\
\hline Independent Variables: & & \\
\hline
\end{tabular}




\begin{tabular}{|l|l|l|}
\hline Training \& Development & 7 & .774 \\
\hline Feedback \& Coaching & 6 & .873 \\
\hline Performance Appraisal & 5 & .848 \\
\hline Rewarding System & 6 & .809 \\
\hline
\end{tabular}

In this report, reliability is measured by using Cronbach's Alpha. Cronbach's Alpha measures internal consistency or how the items are closely related as a group. Cronbach's Alpha of .07 and above is acceptable where scale between 0 (no internal reliability) and 1 (greatest internal reliability). Cronbach's Alpha for dependent variable has shown in the table which is greater than benchmark .07, which indicates good and acceptable in the rules of thumb, therefore the questionnaire formed is reliable.

\section{Descriptive Statistics Analysis:}

Table 2: Descriptive Statistics

\begin{tabular}{|c|c|c|c|c|}
\hline & $\mathrm{N}$ & \multicolumn{2}{|c|}{ Mean } & Std. Deviation \\
\hline & Statistic & Statistic & Std. Error & Statistic \\
\hline Feedback \& Coaching & 61 & 2.3716 & .10177 & .79489 \\
\hline Performance Appraisal & 61 & 2.4656 & .10462 & .81709 \\
\hline Rewarding System & 61 & 2.2732 & .08237 & .64337 \\
\hline Training \& Development & 61 & 2.1569 & .07299 & .57006 \\
\hline
\end{tabular}

The table has shown the statistical description of PMS dimensions and Employee Performance. From the table it has been found that employees of the organization perceived that Performance Appraisal (with highest mean scores i.e. $\mathrm{M}=2.4656 \mathrm{SD}=.81709$ ) to be the most dominant practices of PMS and evident to a considerable extent, followed by Feedback \& Coaching $(\mathrm{M}=2.3716 \mathrm{SD}=.79489)$, Rewarding System $(\mathrm{M}=2.2732 \mathrm{SD}=.64337)$, Training \& Development $(\mathrm{M}=2.1569 \mathrm{SD}=.57006)$.

\section{Correlation Analysis:}

Table 3: Correlation Alalysis

\begin{tabular}{|c|c|c|c|c|c|c|}
\hline \multicolumn{7}{|l|}{ Correlations } \\
\hline & & $\begin{array}{l}\text { Employee } \\
\text { Performance }\end{array}$ & $\begin{array}{l}\text { Training \& } \\
\text { Development }\end{array}$ & $\begin{array}{l}\text { Feedback } \\
\& \\
\text { Coaching }\end{array}$ & $\begin{array}{l}\text { Performance } \\
\text { Appraisal }\end{array}$ & $\begin{array}{l}\text { Rewarding } \\
\text { System }\end{array}$ \\
\hline $\begin{array}{l}\text { Employee } \\
\text { Performance }\end{array}$ & $\begin{array}{l}\text { Pearson } \\
\text { Correlation }\end{array}$ & 1 & & & & \\
\hline $\begin{array}{l}\text { Training \& } \\
\text { Development }\end{array}$ & $\begin{array}{l}\text { Pearson } \\
\text { Correlation }\end{array}$ & $.522 * *$ & 1 & & & \\
\hline $\begin{array}{l}\text { Feedback \& } \\
\text { Coaching }\end{array}$ & $\begin{array}{l}\text { Pearson } \\
\text { Correlation }\end{array}$ & $.280 *$ & $.569 * *$ & 1 & & \\
\hline $\begin{array}{l}\text { Performance } \\
\text { Appraisal }\end{array}$ & $\begin{array}{l}\text { Pearson } \\
\text { Correlation } \\
\end{array}$ & .230 & $.348 * *$ & $.648 * *$ & 1 & \\
\hline Rewarding System & $\begin{array}{l}\text { Pearson } \\
\text { Correlation }\end{array}$ & .068 & .080 & .248 & $.446 * *$ & 1 \\
\hline \multicolumn{7}{|c|}{ **. Correlation is significant at the 0.01 level (2-tailed). } \\
\hline *. Correlation is sig & cant at the 0 . & (2-tailed). & & & & \\
\hline
\end{tabular}

The table of correlation shows that Training \& Development ( $\mathrm{r}=0.522)$ is highly correlated with employee performance. And Feedback \& Coaching $(\mathrm{r}=0.280)$ is moderately correlated with employee performance. Performance Appraisal ( $\mathrm{r}=0.230)$ and Rewarding System $(\mathrm{r}=0.068)$ have negatively correlated with employee performance.

\section{Hypotheses Development:}

According to the factors I got from the respondents I have develop four hypotheses. Those are given below-

H1: If effective feedback and coaching is given to employees on their progress towards their goals, employee performance will improve. People need to know in a timely manner how they're doing, what's working, and what's not. Feedback \& Coaching significantly influence employee job satisfaction. 
H2: Training \& Development is the most significant factor required to obtain maximum output from the human resources. It can be used to improve or develop job related performance requirements of the employees. Training \& Development significantly influence employee satisfaction.

H3: Performance Appraisal acts as an important part of measuring employee performance. It evaluates the effectiveness of the whole process and its contribution to overall organizational performance to allow changes and improvements to be made. It significantly influences employee satisfaction.

H4: If the employees are paid a good reward, their productivity will increase. The effectiveness of pay-for performance has a direct influence on high levels of productivity and desirable work attitudes. Rewarding Systems significantly influence employee satisfaction.

\section{Testing Hypotheses:}

\subsection{Hypothesis Testing on Independent Variable- Feedback \& Coaching}

H0: Feedback \& Coaching doesn’t significantly influence employee job satisfaction.

H1: Feedback \& Coaching significantly influences employee job satisfaction.

Table 4: Model Summary of Feedback \& Coaching

\begin{tabular}{|c|r|r|r|r|}
\hline \multicolumn{6}{|l|}{ Model Summary } \\
\hline Model & R & R Square & Adjusted R Square & Std. Error of the Estimate \\
\hline 1 & $.280^{\mathrm{a}}$ & .078 & .063 & .63973 \\
\hline
\end{tabular}

a. Predictors: (Constant), Feedback \& Coaching

The model summary table of regression analysis shows the strength of regression is commendably significant as supported by the coefficient of the multiple $\mathrm{R}$ value $=.280$ or $28 \%$. Additionally, the adjusted R-square value of .063 or $6.3 \%$ withholds the variables mentioned, while other $72 \%$ is possibly concerned with associated with variables not similar to chapter involved.

Table 5: Coefficient of Feedback \& Coaching

\begin{tabular}{|c|c|c|c|c|c|c|}
\hline \multicolumn{7}{|c|}{ Coefficients $^{\mathbf{a}}$} \\
\hline \multicolumn{2}{|c|}{ Model } & \multicolumn{2}{|c|}{ Unstandardized Coefficients } & \multirow{2}{*}{$\begin{array}{c}\begin{array}{c}\text { Standardized } \\
\text { Coefficients }\end{array} \\
\text { Beta }\end{array}$} & \multirow[t]{2}{*}{$\mathrm{t}$} & \multirow[t]{2}{*}{ Sig. } \\
\hline & & $\mathrm{B}$ & Std. Error & & & \\
\hline \multirow[t]{2}{*}{1} & (Constant) & 1.446 & .260 & & 5.569 & .000 \\
\hline & Feedback \& Coaching & .232 & .104 & .280 & 2.237 & .029 \\
\hline \multicolumn{4}{|c|}{ a. Dependent Variable: Employee Performance } & & & \\
\hline
\end{tabular}

Moreover, the p-values observed above (Sig $=.000$ and .029$)$ authenticates the degree of significance between the tested variables at a commendable $1 \%$ level, which is also reaffirmed by the $\mathrm{t}$-stat (Feedback \& Coaching $=2.237)$ satisfying $\mathrm{t}>(-/+) 2$. On a parallel note, the coefficient $(\mathrm{B}=.280)$ suggests that there is a strong positive correlation between Legal dimension of Coaching \& Feedback and employee performance.

Table 6: ANOVA of Feedback \& Coaching

\begin{tabular}{|c|c|c|c|c|c|c|}
\hline \multicolumn{7}{|c|}{ ANOVA $^{b}$} \\
\hline \multicolumn{2}{|c|}{ Model } & Sum of Squares & $\mathrm{df}$ & Mean Square & $\mathrm{F}$ & Sig. \\
\hline \multirow[t]{3}{*}{1} & Regression & 2.048 & 1 & 2.048 & 5.005 & $.029^{\mathrm{a}}$ \\
\hline & Residual & 24.146 & 59 & .409 & & \\
\hline & Total & 26.194 & 60 & & & \\
\hline
\end{tabular}

a. Predictors: (Constant), Feedback \& Coaching

b. Dependent Variable: Employee Performance

From the above table reveals that the degree of freedom associates with SSR will always be 1 for the sample linear regression model. The degree of freedom associate with $\mathrm{SSR}$ is $=\mathrm{n}-1=61-1=60$.

With regard to the ANOVA table, it is identified that the value of F-stat is 5.972 and is significant as the level of significance .029 is less than $5 \%(\mathrm{p}<0.05)$. 
This indicates that the overall model was reasonable fit and there was a statistically significant association between employee Coaching \& feedback and employee performance. So H1 is accepted and H0 is rejected. Additionally, this also indicated that the hypothesis of this study is accepted i.e., coaching $\&$ feedback has a positive relationship with employee performance.

\subsection{Hypothesis Testing on Independent Variable- Training \& Development}

H0: Training \& Development doesn't significantly influence employee job satisfaction.

H1: Training \& Development significantly influences employee job satisfaction.

Table 7: Model Summary of Training \& Development

\begin{tabular}{|c|c|c|c|c|}
\hline \multicolumn{5}{|c|}{ Model Summary } \\
\hline Model & $\mathrm{R}$ & R Square & Adjusted R Square & Std. Error of the Estimate \\
\hline 1 & $.522^{\mathrm{a}}$ & .272 & .260 & .56848 \\
\hline
\end{tabular}

The model summary table of regression analysis shows the strength of regression is commendably significant as supported by the coefficient of the multiple $\mathrm{R}$ value $=.522$ or $52.2 \%$. Additionally, the adjusted R-square value of .260 or $2.6 \%$ withholds the variables mentioned, while other $47.8 \%$ is possibly concerned with associated with variables not similar to chapter involved.

Table 8 : Coefficient of Training \& Development

\begin{tabular}{|c|c|c|c|c|c|c|}
\hline \multicolumn{7}{|c|}{ Coefficients $^{\mathrm{a}}$} \\
\hline \multicolumn{2}{|c|}{ Model } & \multicolumn{2}{|c|}{ Unstandardized Coefficients } & \multirow{2}{*}{$\begin{array}{c}\begin{array}{c}\text { Standardized } \\
\text { Coefficients }\end{array} \\
\text { Beta }\end{array}$} & \multirow[t]{2}{*}{$\mathrm{t}$} & \multirow[t]{2}{*}{ Sig. } \\
\hline & & $\mathrm{B}$ & Std. Error & & & \\
\hline \multirow[t]{2}{*}{1} & (Constant) & .693 & .287 & & 2.415 & .019 \\
\hline & Training \& Development & .605 & .129 & .522 & 4.696 & .000 \\
\hline
\end{tabular}

Moreover, the p-values observed above ( $\mathrm{Sig}=.019$ and .000$)$ authenticates the degree of significance between the tested variables at a commendable $1 \%$ level, which is also reaffirmed by the $t$-stat (Training \& Development $=4.696)$ satisfying $t>(-/+)$. On a parallel note, the coefficient $(\mathrm{B}=.522)$ suggests that there is a strong positive correlation between Legal dimension of Training $\&$ Development and employee performance.

Table 9: ANOVA of Training \& Development

\begin{tabular}{|c|c|c|c|c|c|c|}
\hline \multicolumn{7}{|c|}{ ANOVA $^{b}$} \\
\hline \multicolumn{2}{|c|}{ Model } & Sum of Squares & df & Mean Square & $\mathrm{F}$ & Sig. \\
\hline \multirow[t]{3}{*}{1} & Regression & 7.127 & 1 & 7.127 & 22.052 & $.000^{\mathrm{a}}$ \\
\hline & Residual & 19.067 & 59 & .323 & & \\
\hline & Total & 26.194 & 60 & & & \\
\hline \multicolumn{7}{|c|}{ a. Predictors: (Constant), Training \& Development } \\
\hline \multicolumn{5}{|c|}{ b. Dependent Variable: Employee Performance } & & \\
\hline
\end{tabular}

From the above table reveals that the degree of freedom associates with SSR will always be 1 for the sample linear regression model. The degree of freedom associate with SSR is $=n-1=61-1=60$.

With regard to the ANOVA table, it is identified that the value of F-stat is 22.052 and is significant as the level of significance .000 is less than $5 \%(\mathrm{p}<0.05)$.

This indicates that the overall model was reasonable fit and there was a statistically significant association between employee Training \& Development and employee performance. So H1 is accepted and H0 is rejected. Additionally, this also indicated that the hypothesis of this study is accepted i.e., Training \& Development has a positive relationship with employee performance. 


\subsection{Hypothesis Testing on Independent Variable- Performance Appraisal}

H0: Performance Appraisal doesn’t significantly influence employee job satisfaction.

H1: Performance Appraisal significantly influences employee job satisfaction.

Table 10: Model Summary of Performance Appraisal

\begin{tabular}{|c|c|c|c|c|}
\hline \multicolumn{4}{|l|}{ Model Summary } \\
\hline Model & $\mathrm{R}$ & R Square & Adjusted R Square & Std. Error of the Estimate \\
\hline 1 & $.230^{\mathrm{a}}$ & .053 & .037 & .64847 \\
\hline
\end{tabular}

The model summary table of regression analysis shows the strength of regression is commendably significant as supported by the coefficient of the multiple $\mathrm{R}$ value $=.230$ or $23.0 \%$. Additionally, the adjusted R-square value of .037 or $3.7 \%$ withholds the variables mentioned, while other $77 \%$ is possibly concerned with associated with variables not similar to chapter involved.

Table 11: Coefficient of Performance Appraisal

\begin{tabular}{|c|c|c|c|c|c|c|}
\hline \multicolumn{7}{|c|}{ Coefficients $^{\mathrm{a}}$} \\
\hline \multicolumn{2}{|c|}{ Model } & \multicolumn{2}{|c|}{ Unstandardized Coefficients } & \multirow{2}{*}{$\begin{array}{c}\text { Standardized } \\
\text { Coefficients } \\
\text { Beta }\end{array}$} & \multirow[b]{3}{*}{5.788} & \multirow[t]{2}{*}{ Sig. } \\
\hline \multirow{3}{*}{1} & & & 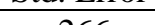 & & & \\
\hline & (Constant) & 1.539 & .266 & & & .000 \\
\hline & Performance Appraisal & .186 & .102 & .230 & 1.814 & .075 \\
\hline
\end{tabular}

Moreover, the p-values observed above ( $\mathrm{Sig}=.000$ and .075 ) authenticates the degree of significance between the tested variables at a commendable $1 \%$ level, which is also reaffirmed by the $t$-stat (Performance Appraisal $=1.814$ ) not satisfying $t>(-/+) 2$. On a parallel note, the coefficient $(\mathrm{B}=.230)$ suggests that there is a negative correlation between Legal dimension of Performance Appraisal and employee performance.

Table 12: ANOVA of Performance Appraisal

\begin{tabular}{|c|c|c|c|c|c|c|}
\hline \multicolumn{7}{|c|}{ ANOVA $^{b}$} \\
\hline \multicolumn{2}{|c|}{ Model } & Sum of Squares & $\mathrm{df}$ & Mean Square & $\mathrm{F}$ & Sig. \\
\hline \multirow[t]{3}{*}{1} & Regression & 1.383 & 1 & 1.383 & 3.290 & $.075^{\mathrm{a}}$ \\
\hline & Residual & 24.811 & 59 & .421 & & \\
\hline & Total & 26.194 & 60 & & & \\
\hline \multicolumn{5}{|c|}{ a. Predictors: (Constant), Performance Appraisal } & & \\
\hline \multicolumn{5}{|c|}{ b. Dependent Variable: Employee Performance } & & \\
\hline
\end{tabular}

From the above table reveals that the degree of freedom associates with SSR will always be 1 for the sample linear regression model. The degree of freedom associate with SSR is $=\mathrm{n}-1=61-1=60$.

With regard to the ANOVA table, it is identified that the value of F-stat is 3.290 and is significant as the level of significance .075 is more than $5 \%(\mathrm{p}>0.05)$.

This indicates that the overall model was reasonable fit and there was a statistically no significant association between employee Performance Appraisal and employee performance. So H1 is rejected and H0 is accepted. Additionally, this also indicated that the hypothesis of this study is accepted i.e., Performance Appraisal has a negative relationship with employee performance.

\subsection{Hypothesis Testing on Independent Variable- Rewarding System}

H0: Rewarding System doesn't significantly influence employee job satisfaction.

H1: Rewarding System significantly influences employee job satisfaction.

Table 13: Model Summary of Rewarding System 


\begin{tabular}{|c|c|c|c|c|}
\hline \multicolumn{4}{|l|}{ Model Summary } \\
\hline Model & $\mathrm{R}$ & R Square & Adjusted R Square & Std. Error of the Estimate \\
\hline 1 & $.068^{\mathrm{a}}$ & .005 & -.012 & .66476 \\
\hline
\end{tabular}

The model summary table of regression analysis shows the strength of regression is commendably significant as supported by the coefficient of the multiple R value $=.068$ or $6.8 .0 \%$. Additionally, the adjusted R-square value of -.012 or $.1 .2 \%$ withholds the variables mentioned, while other $93.2 \%$ is possibly concerned with associated with variables not similar to chapter involved.

Table 14: Coefficient of Rewarding System

\begin{tabular}{|c|c|c|c|c|c|c|}
\hline \multicolumn{7}{|c|}{ Coefficients $^{\mathbf{a}}$} \\
\hline \multicolumn{2}{|r|}{ Model } & \multicolumn{2}{|c|}{ Unstandardized Coefficients } & \multirow{2}{*}{$\begin{array}{c}\text { Standardized } \\
\text { Coefficients } \\
\text { Beta }\end{array}$} & \multirow[t]{2}{*}{$\mathrm{t}$} & \multirow[t]{2}{*}{ Sig. } \\
\hline & & $\mathrm{B}$ & Std. Error & & & \\
\hline \multirow[t]{2}{*}{1} & (Constant) & 1.838 & .315 & & 5.836 & .000 \\
\hline & Rewarding System & .070 & .133 & .068 & .525 & .601 \\
\hline \multicolumn{4}{|c|}{ a. Dependent Variable: Employee Performance } & & & \\
\hline
\end{tabular}

Moreover, the p-values observed above ( $\mathrm{Sig}=.000$ and .601$)$ authenticates the degree of significance between the tested variables at a commendable $1 \%$ level, which is also reaffirmed by the $\mathrm{t}$-stat (Rewarding System =.525) not satisfying $\mathrm{t}>(-/+) 2$. On a parallel note, the coefficient $(\mathrm{B}=.068)$ suggests that there is a negative correlation between Legal dimension of Rewarding System and employee performance.

Table 15: ANOVA of Rewarding System

\begin{tabular}{|c|c|c|c|c|c|c|}
\hline \multicolumn{7}{|c|}{ ANOVA $^{b}$} \\
\hline \multicolumn{2}{|c|}{ Model } & Sum of Squares & df & Mean Square & $\mathrm{F}$ & Sig. \\
\hline \multirow[t]{3}{*}{1} & Regression & .122 & 1 & .122 & .276 & $.601^{\mathrm{a}}$ \\
\hline & Residual & 26.072 & 59 & .442 & & \\
\hline & Total & 26.194 & 60 & & & \\
\hline \multicolumn{4}{|c|}{ a. Predictors: (Constant), Rewarding System } & & & \\
\hline \multicolumn{5}{|c|}{ b. Dependent Variable: Employee Performance } & & \\
\hline
\end{tabular}

From the above table reveals that the degree of freedom associates with SSR will always be 1 for the sample linear regression model. The degree of freedom associate with SSR is $=n-1=61-1=60$.

With regard to the ANOVA table, it is identified that the value of F-stat is .270 and is significant as the level of significance .601 is less than $5 \%(\mathrm{p}>0.05)$.

This indicates that the overall model was reasonable fit and there was a statistically no significant association between employee Rewarding System and employee performance. So H1 is rejected and Ho is accepted. Additionally, this also indicated that the hypothesis of this study is accepted i.e., Rewarding System has a negative relationship with employee performance.

\section{Output of Hypotheses}

Table 16: Output of Hypotheses

\begin{tabular}{|l|l|l|}
\hline \multicolumn{1}{|c|}{ Hypothesis } & \multicolumn{1}{|c|}{ Output } & \multicolumn{1}{|c|}{ Results } \\
\hline $\begin{array}{l}\text { H1: Feedback \& Coaching } \\
\text { significantly influences employee } \\
\text { job satisfaction. }\end{array}$ & $\begin{array}{l}\text { Output (1) As the P value is less than 0.05 (in table 12), so I accept the } \\
\text { alternative hypotheses along with concluding that there is significant } \\
\text { association between Feedback \& Coaching and Employee Performance. }\end{array}$ \\
\hline $\begin{array}{l}\text { H2: Training \& Development } \\
\text { significantly influence employee } \\
\text { satisfaction. }\end{array}$ & $\begin{array}{l}\text { Output (2) As the P value is less than 0.05 (in table 15), so I accept the } \\
\text { alternative hypotheses along with concluding that there is a significant } \\
\text { relation between Training \& Development and Employee Performance. }\end{array}$ \\
\hline
\end{tabular}




\begin{tabular}{|l|l|l|c|}
\hline $\begin{array}{l}\text { H3: Performance Appraisal } \\
\text { significantly influence employee } \\
\text { satisfaction. }\end{array}$ & $\begin{array}{l}\text { Output (3) As the P value is greater than 0.05 (in table 18), so I reject the } \\
\text { alternative hypotheses along with concluding that there is no significant } \\
\text { relation between Performance Appraisal and Employee Performance. }\end{array}$ & Rejected \\
\hline $\begin{array}{l}\text { H4: Rewarding Systems } \\
\text { significantly influences employee } \\
\text { satisfaction. }\end{array}$ & $\begin{array}{l}\text { Output (4) As the P value is greater than 0.05 (in table 21), so I reject the } \\
\text { alternative hypotheses along with concluding that there is no significant } \\
\text { relation between Rewarding Systems and Employee Performance. }\end{array}$ & Rejected \\
\hline
\end{tabular}

\section{FINDINGS}

In this section, a list of findings has been shown according to analysis and objectives of the report.

Feedback \& Coaching gives recognition for good performance hence improved employee productivity. The study finds out that Feedback \& Coaching strongly suggests changes to improve departmental services and outcomes hence create room for improvement. Actual performance could therefore be compared to the desired performance; therefore, the outcome is evaluated and a development plan is set based on the weakness.

From the analysis we also find that there is a strong relationship between training \& development and employee performance. The dimension of training a\& development of PMS has significantly impact on employee performance. The data also establishes that training and development (T\&D) policy ensures employees are exposed to relevant skills to improve productivity. From the analysis it is clear that Training and development (T\&D) opportunities provided encourage staff to be creative hence improved productivity.

The study finds out that there are no links between performance appraisal and employee performance as indicated. Performance appraisal doesn't give recognition for good performance. Performance appraisal does not suggest changes to improve departmental services and outcomes.

According to my analysis there is no significant relation between rewarding systems and employee performance. Frequent rewards provided by the company does not challenge staffs to work hard. The rewarding system also does not motivate the staffs to complete their duties timely. The staffs are not encouraged to be creative by the reward opportunities.

From the results of the study performance management system enables employees meet all their work targets and deadlines promptly hence improved individual employee productivity. Finally, performance management enables employees arrive on time to work and to meetings and therefore save time in their work hence maximum employee productivity.

\section{RECOMMENDATIONS}

It is recommended that Consumer Food Products Ltd should identify areas of improvement in the implementation of performance management system and align their practice(s) with national norms and standards. It is also should modify its performance appraisal system. Performance appraisal should be fair to all employees supervised. Performance appraisal can make changes to improve departmental services and outcomes. The rewarding systems also need to change to improve the effectiveness of the performance of employee. Consumer Food Products Ltd. can set itself as a market leader in case of employee performance sector by maintaining appropriate PMS rules, regulations, and policy in the organization.

\section{CONCLUSION}

This research was carried out with a main purpose of finding out the Influence of Performance Management System on Employee performance. The general objective of the study was to determine the Influence of PMS on Employee performance in Food Products Ltd. The specific research objectives that guided the study were; to determine the extent to which development of performance plans influences Employee performance in consumer Food Products Ltd, to assess the extent to which review of employee progress on an ongoing basis influences Employee performance in consumer Food Products Ltd, to assess the extent to which training and development of employee needs influences Employee performance in consumer Food Products Ltd and to assess the extent to which rewarding of employees influences Employee performance in consumer Food Products Ltd.

Training \& development of employee progress on ongoing basis influences employee productivity to a greater extend as indicated by the findings. Actual performance could be compared to the desired performance; therefore, the outcome is evaluated and a development plan is set based on the weakness. Coaching \& feedback also influences productivity. Effective and efficient Coaching \& feedback policies should be put in place to continuously equip staff with skill. As technology changes there is need for a continuous improvement 
and adaptability to technology. In performance management, rewarding systems influence employee productivity. A reward motivates, attracts and retains the right kind of people hence facilitates the implementation of strategy.

\section{REFERENCES}

[1] Adhikari, D. R. (2010). Human resource development (HRD) for performance management The case of Nepalese organizations. International Journal of Productivity d Performance Management, pp. 306-324.

[2] Almothaseb, A. A., Almahameed, M. A., \& Tobeery. (June 2017). The Impact of Performance Management System on Employee Performance: The Moderating Role of Balance Scorecard Usage. International Review of Management and Business Research, Vol. 6(Issue.2), 682.

[3] Armstrong, M. (1994). Performance Management: Key strategies and practical guidelines. London,UK: Kogan Page Limited.

[4] Assish, D. J. (March 2018). FACTORS THAT INFLUENCE THE EFFECTIVENESS OF PERFORMANCE MANAGEMENT SYSTEM ADOPTION IN ORGANISATION. Global Journal of Human Resource Management, Vol.6, 51-52.

[5] Beckons, A. c. (n.d.). Performance management in India.

[6] Desseler, G. (2007). Human Resource Management. New Delhi: Printice Hall of India.

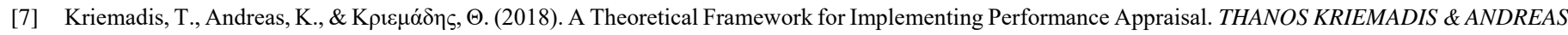
KOTSOVOS.

[8] Nassazi, A. (2013). EFFECTS OF TRAINING ON EMPLOYEE PERFORMANCE: Evidence from Uganda. Business Economics and Tourism.

[9] Olufemi, J. (n.d.). Performance Management Systems and Productivity in the Public Sector: WITHER AFRICAN PUBLIC ADMINISTRATION. Africa's Public Service Delivery \& Performance Review, pp 77-105.

[10] Pulakos, E. D. (n.d.). Performance Management: A roadmap for developing,implementing and evaluating performance management systems . : Shrm Fundation.

[11] Rastislav, R., \& Petra, L. (September 2016). Strategic Performance Management System and Corporate Sustainability Concept - Specific Parametres in Slovak Enterprises. Journal of Competitiveness, 108.

[12] Richard, H., \& Ruth, W. (2005). A THEORY OF TEAM COACHING. Academy of Management Review, pp 269-287.

[13] Tomić, S., Tadić, J., \& Sedlak, O. (November 2016.). Analysis of the Aspects of Performance Management System. TEM Journal, Volume 5,(Issue 4,), 452.

[14] Zulystiawati. (Vol.3, No.4, 2014). Performance Management System: The Practices in the Public Organization in the Developing Countries. (I. 2.-5.-8. (Online), Ed.) Information and Knowledge Management, 126.

[15] Zvavahera, P. (n.d.). An evaluation of the effectiveness of performance management systems on service delivery in the Zimbabwean civil service. Journal of Management and Marketing Research, pp 1-8.

First Author - Md. Aktaruzzaman Santi, BBA (Bangladesh), MBA (Bangladesh)

University of Barishal, Barishal-8200, Bangladesh

Santibu069@gmail.com

\section{Second Author - Abdur Rahim,}

BBA (Bangladesh), MBA (Bangladesh)

University of Barishal, Barishal-8200, Bangladesh

Armgt372@gmail.com 